\title{
Effects of Environmental Factors on Corporate Strategy and Performance of Manufacturing Industries in Indonesia
}

\author{
Rachmad Hidayat, Sabarudin Akhmad, Mu'alim \\ Industrial Engineering Department, University of Trunojoyo Madura (Indonesia) \\ rachmad_h@ymail.com,dr.rachmad.mt@gmail.com,alimmin@yahoo.com
}

Received: November 2014

Accepted: May 2015

\section{Abstract:}

Purpose: the purpose of this study was to examine and obtain empirical evidence of the effects of external and internal environmental factors on the strategy and performance of manufacturing companies.

Design/methodology/approach: This study used primary data obtained by distributing questionnaires to 150 respondents of manufacturing companies in Indonesia spreading over six major cities in Java such as Jakarta, Banten, Bandung, Yogyakarta, Semarang and Surabaya. Samples were taken by using the systematic random sampling technique. The technique was used since those major cities had different numbers of manufacturing companies. Subsequently, the feasibility of the model was tested. Several indices of model feasibility would be used to test the model developed in this structural equation model. In case of a sub-optimal model, a model modification was to be performed by adding or removing paths so that the chi-square values would decrease by the values of the index.

Findings: Results showed that internal and external environmental factors, through the operating environments and the remote environments of manufacturing industries, jointly affected the companies' understanding of the condition of the industrial environments to establish strategic goals in order to achieve optimal performance of manufacturing industry. 
Practical implications: The internal and external environmental factors through the operating and remote environments had effects on the strategy of manufacturing companies in Indonesia. However, both internal and external environments did not affect the performance of manufacturing companies in Indonesia. There was a tendency that manufacturing companies were to observe the occurring macro-economic conditions. Manufacturing industries were faced with the pressures from competition, customers and suppliers that affected companies' revenue. Performance of manufacturing industries was more influenced by macro-economic conditions that have not recovered from the global crisis.

Originality/value: This study was conducted to determine the effects of environmental factors on the corporate strategy and performance. The effects of the industrial environments are crucial since the more complicated changes in the industrial environments the greater the impacts it has on the resources, structures and processes in the company. Environmental factors of the industry present both organizational strengths and weaknesses, which would affect the strategy and performance of the industry.

Keywords: environment, corporate strategy, performance and manufacturing industries

\section{Introduction}

The industrial sector plays an important role in the Indonesian economy. In general, this sector considerably contributes to the formation of the Gross Domestic Product (GDP) and foreign exchange earnings. It is believed that the industrial sector is the one capable of leading other sectors in an economy that is geared towards progress. Industrial products constantly have higher terms of trade and create greater added values than other products. This is due to the fact that the industrial sector has a wide variety of products and is capable of providing the users with high benefits (Dumairy, 2000).

Statistics Indonesia (known as the BPS, Badan Pusat Statistik) reported that Indonesian large and medium scale manufacturing industries grew by $4.12 \%$ in 2013 compared to that of the previous year. However, that growth relatively plateaued in comparison to that of the previous year. In 2013, the similar industries also slightly rose by $4.1 \%$. The BPS reported that, until the last quarter of 2013, the large-scale manufacturing industries recorded a positive performance in October and November by $10.04 \%$ and $0.01 \%$, respectively. Unfortunately, in November 2013, the industry experienced a contraction with an attenuated growth of $3.26 \%$. Amidst the growth of the manufacturing sector, the BPS recorded that there were many industries experiencing a decline in production throughout January to December of 2013. The largest decline was experienced by the base metal industry, whose performance slumped by 
$8.48 \%$ in comparison to that of the previous year. The textile industry also experienced a decrease of $8.32 \%$, while unclassified machinery and equipment industry decreased by $8.31 \%$.

In 2013 , the national manufacturing industry grew by $6.40 \%$. The figure was higher than the 2013 economic growth (GDP), which was 6.23\%. Fertilizer, chemical, and rubber material sector enjoyed growth of $10.25 \%$; cement and non-metal mineral product sector $7.85 \%$; food, beverage and tobacco 7.74\%; and transport vehicle, machine tool, and equipment sector $6.94 \%$. The growth of the manufacturing industry was supported by the high level of investment in the domestic industrial and consumption sector. This sector contributed up to $20.85 \%$ of the national GDP. Meanwhile, the exports of manufacturing product for January to November of 2013 contributed up to $60.02 \%$ of the total national exports. With regard to exports, non-oil exports of industrial products during January to November of 2013 reached US $\$ 107.05$ billion. The figure contributed $60.02 \%$ of the total national exports. In 2013 , exports of industrial products were targeted to rise up to US \$ 125 billion. This represented the target for 2013, which was part of the long-term development of national industry.

According to Pearce and Robinson (2003: page 57) external (business) environments can be grouped into three interrelated categories: the operating environments, the industrial environments and the remote environments. Operating environments, also called the competitive or task environments, are those factors in a competitive situation that affect the success of a company in acquiring the needed resources and/or in marketing its products and services profitably. According to Pearce and Robinson (2003: page 82), some of these factors include: the competitive position of the company, the reputation of the company in the eyes of suppliers/sellers and creditors. Kotler and Armstrong (2013: page 148) identified the remote environments as the main macro-environments that include natural and technological environments, social environments, economic and cultural environments, and political, law and security environments.

According to Wheelen and Hunger (2012: page 162), internal factors are those strategic factors that need to be analyzed and diagnosed by the management in determining the strengths and weaknesses of the company. The indicators of internal factors are: (1) marketing and distribution; (2) research and development; (3) operations and production management; (4) human resources, and (5) finance and accounting.

A corporate strategy is commonly used to describe the pattern of decisions that determine the objectives of the company, resulting in basic policies to achieve business objectives. Collis and Montgomery (2005: page 8) defines a corporate strategy as the means of the company to create values through configuring and coordinating multi-business activities. Based on the theory of corporate strategy, a study can be performed on a single business (Pearce \& Robinson, 2003; Parnell, 2013; Hitt, Ireland \& Hoskisson, 2005: page 185) since not all of the manufacturing companies that are the object of the study are multi-business companies. 
Corporate strategy focuses on diversification strategy with indicators: product diversity, technological linkage and market diversity.

Performance is a company's achievements for a certain period, which reflects the level of corporate health. Chi, Kilduff and Gargeya (2009) argue that a more comprehensive corporate performance is based on the achievement of strategic objectives. Performance is measured on the basis of: (1) financial perspective with regard to increased returns, increased sales and improved cost effectiveness; (2) customer perspective in terms of improvements in confidence and cost reduction strategies; (3) business process perspective with regard to an increase in service quality and integrated customer service; and (4) learning and commitment perspective including an increased productivity and personnel commitment.

The present study was conducted on large manufacturing industries in Indonesia. Performance of manufacturing industry was more influenced by macro-economic conditions that have not recovered from the global crisis. These conditions were also exacerbated by the increase in fuel prices for industries and the heated political conditions ahead of the legislative and presidential elections. In recent unfavorable situations, most of the studied industries preferred a concentric diversification strategy (creating new products with technological linkage to the existing ones) (Hidayat \& Hairil, 2009).

This study was conducted to determine the effects of environmental factors on the corporate strategy and performance. The effects of the industrial environments are crucial since the more complicated changes in the industrial environments, the greater the impacts it has on the resources, structures and processes in the company. Environmental factors of the industry present both organizational strengths and weaknesses, which would affect the strategy and performance of the industry. Wheelen and Hunger (2012: page 87) argue that, in order to achieve optimal performance, a strategy must be formulated with due regard to the environment. A company's successful competitive strategy leads to victory in the face of market competition and competitors in terms of product innovation (Babatunde \& Adebisi, 2012). Thus, the purpose of this study was to examine and obtain empirical evidence of the effects of external and internal environmental factors on the strategy and performance of manufacturing companies.

\section{Methods}

This study used primary data obtained by distributing questionnaires to 150 respondents of manufacturing companies in Indonesia spreading over six major cities in Java such as Jakarta, Banten, Bandung, Yogyakarta, Semarang and Surabaya. Samples were taken by using the systematic random sampling technique. The technique was used since those major cities had different numbers of manufacturing companies. The Likert scale of 1 to 5 was used. Variables 
included industrial environments, operating environments, remote environments, internal environments, corporate strategies and corporate performance. The structural equation model expressing the causal relationships among variables was:

$$
Y_{2}=\beta_{1} X_{1}+\beta_{2} X_{2}+\beta_{3} X_{3}+\beta_{4} X_{4}+\beta_{5} Y_{1}+Z_{1}
$$

The measurement models determining the indicators capable of measuring the latent variables were:

$$
\begin{gathered}
X_{1 . i}=\lambda_{i} X_{1}+e_{i,} i=1, \ldots 4 \\
X_{2 . i}=\lambda_{4+i} X_{2}+e_{4+i}, i=1, \ldots 3 \\
X_{3 . i}=\lambda_{7+i} X_{3}+e_{7+i}, i=1, \ldots 3 \\
X_{4 . i}=\lambda_{10+i} X_{4}+e_{10+i}, i=1, \ldots 5 \\
Y_{1 . i}=\lambda_{15+i} Y_{1}+e_{15+i}, i=1, \ldots 3 \\
Y_{2 . i}=\lambda_{18+i} Y_{2}+e_{18+i}, i=1, \ldots 4
\end{gathered}
$$

Notes: $Y_{2}=$ performance; $Y_{1}=$ corporate strategy; $\beta_{1}, \beta_{2}, \beta_{3}, \beta_{4}=$ regression weight; $X_{1}=$ industrial environments; $X_{2}=$ operating environments; $X_{3}=$ remote environments; $X_{4}=$ internal environments. The research framework is as Figure 1.

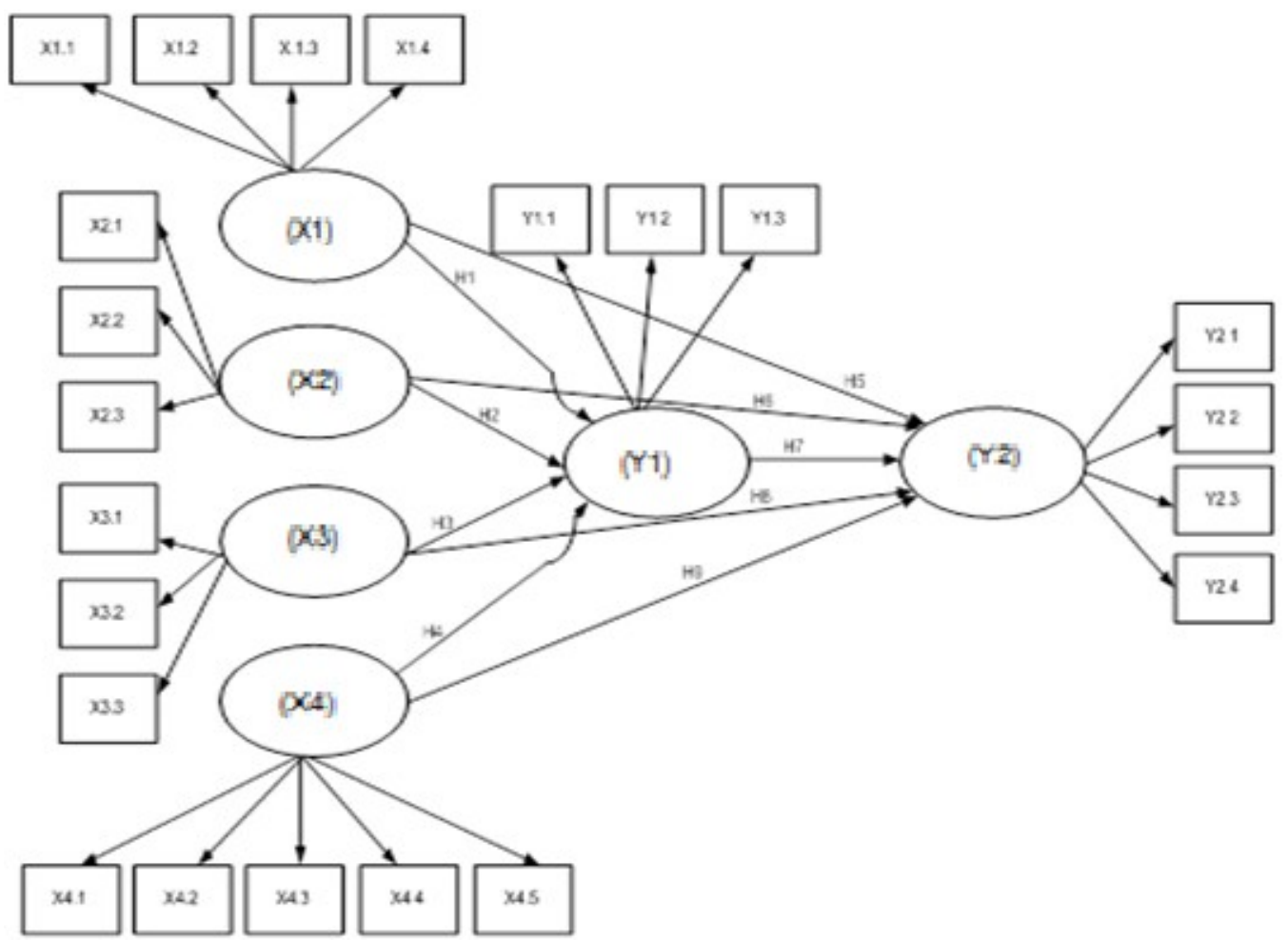

Figure 1. The research framework 
Notes: $X_{1.1}=$ threat of new entrants; $X_{1.2}=$ strength of the buyer/seller; $X_{1.3}=$ threat of substitute products; $X_{1.4}=$ competition among members of the industry; $X_{2.1}=$ competitive position of the company; $X_{2.2}=$ company's reputation in the eyes of suppliers; $X_{2.3}=$ company's reputation in the eyes of creditors; $X_{3.1}=$ nature and technology; $X_{3.2}=$ socio-economy and culture; $X_{3.3}=$ politics, laws and security; $X_{4.1}=$ marketing and distribution; $X_{4.2}=$ research and development; $X_{4.3}=$ operations and production Management; $X_{4.4}=$ human resources, $X_{4.5}=$ finance and accounting; $Y_{1.1}=$ product diversity: $Y={ }_{1.2}$ technological linkage; $Y_{1.3}=$ market diversity; $Y_{2.1}=$ financial perspective; $Y_{2.2}=$ customer perspective; $Y_{2.3}=$ business process perspective; $Y_{2.4}=$ learning and commitment perspective.

Hypotheses proposed in this study were:

Hypotheses 1. The industrial environments had a significant effect on the corporate strategy of manufacturing industries in Indonesia..

Hypotheses 2. The operational environments had a significant effect on the corporate strategy of manufacturing industries in Indonesia.

Hypotheses 3. The remote environments had a significant effect on the corporate strategy of manufacturing industries in Indonesia.

Hypotheses 4. The internal environments had significant effects on corporate strategy of manufacturing industries in Indonesia.

Hypotheses 5. The industrial environments had significant effects on the performance of manufacturing industries in Indonesia.

Hypotheses 6. The operating environments had significant effects on the performance of manufacturing industries in Indonesia.

Hypotheses 7. The remote environments had a significant effect on the performance of manufacturing industries in Indonesia.

Hypotheses 8. The internal environments had a significant effect on the performance of manufacturing industries in Indonesia.

Hypotheses 9. The corporate strategy had significant effects on the performance of manufacturing industries in Indonesia.

Subsequently, the feasibility of the model was tested. Several indices of model feasibility would be used to test the model developed in this structural equation model. In case of a sub-optimal model, a model modification was to be performed by adding or removing paths so that the chisquare values would decrease by the values of the index (Ferdinand, 2000: page 59). 


\section{Result and Discussion}

Instruments were subjected to validity and reliability tests. An instrument was considered valid if the significance value was less than 5\%. (Ghozali, 2009: page 84). The purpose of reliability tests was to determine the level of reliability of the questionnaire, or whether a person's answers to statements were consistent or stable. An instrument was considered reliable if the Cronbach's alpha was greater than 0.6. (Ghozali, 2009: page 102). Results of the validity tests showed that all indicators of the study were valid as indicated by the sig. value (2-tailed) of $0.000<0.05$. This indicated that the measures used in the study were appropriate. Reliability tests showed that all the 22 indicators of the study were reliable indicator as indicated by the value of Cronbach's alpha of $0.804>0.6$. This indicated that respondents were stable in answering the statements of the study questionnaire.

Confirmatory tests of all indicators were performed in order to measure the latent variables with a cutoff value of 0.5 . Results for exogenous variables indicated that there were four indicators with a value of less than 0.5 and for endogenous variables there was one indicator with a value of less than 0.5 .

\subsection{SEM Analysis}

Prior to performing a structural equation modeling (SEM) analysis, SEM assumptions were subjected to normality test, outlier test and multicollinearity test. Data was considered normal if the multivariate critical ratio was $-2.58<$ c.r. $>2.58$. (Kline, 2011). The normality test indicated that data was multivariate normal with a multivariate critical ratio of 1.959 . This means that data was normally distributed with a sample of 150 respondents. SEM analysis generated the initial model as shown in Figure 2.

Figure 2 shows that the result of the chi-square $(\chi 2)$ goodness-of-fit test $=197.233$, $p=0.000$; it means that the model for testing the study hypotheses was not good one. Thus, a modification was performed by considering the alternative modifications in the modification indices in order to refine the model. An unfit model is allowed to be modified by modification indices as recommended by AMOS program (Mustafa \& Wijaya, 2012). The final model after model modification is shown in Figure 3.

Based on Figure 3, a conclusion can be drawn that the chi square $(\chi 2)=101.479, p=0.154$ and other tests showed that model was a good one. This means that the analyzed model was fit in overall or that theoretically there was no difference between the model and empirical data. 


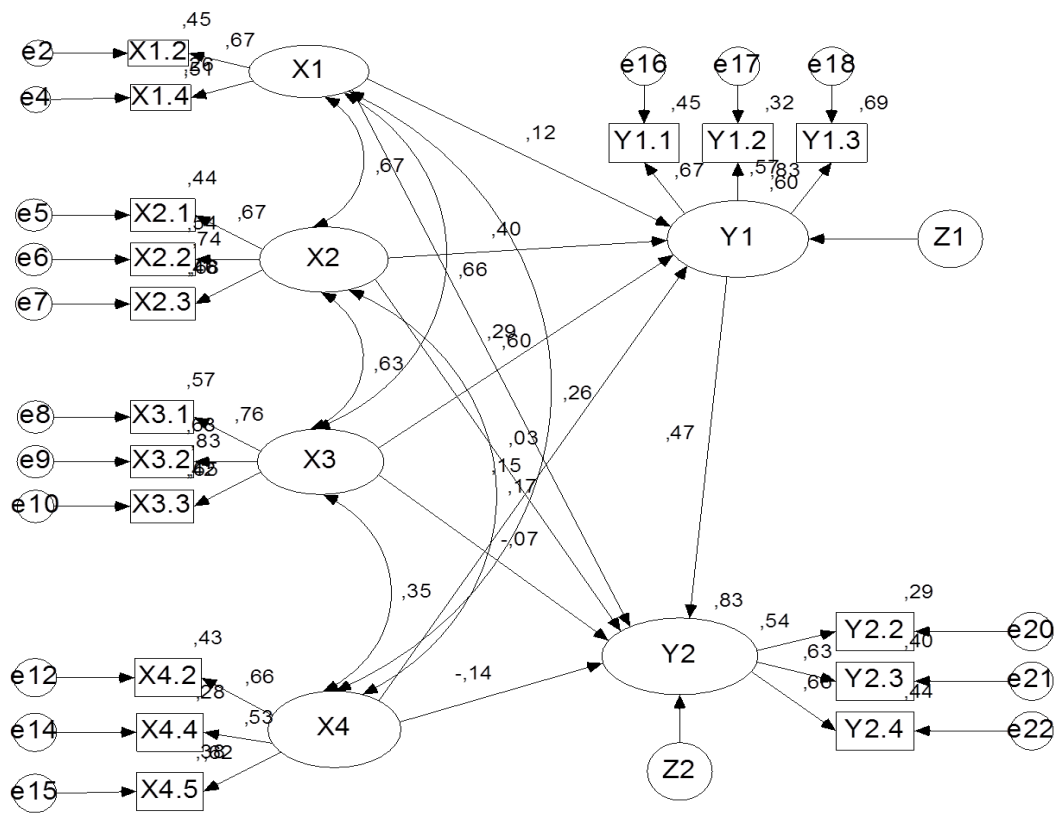

Chi Square: 197,233

Prob: 000

df: 104

RMSEA:,081

$\mathrm{GFI}:, 866$

AGFI:,803

TLI:,827

$\mathrm{CFI}, 868$

Figure 2. Results of early-stage SEM analysis

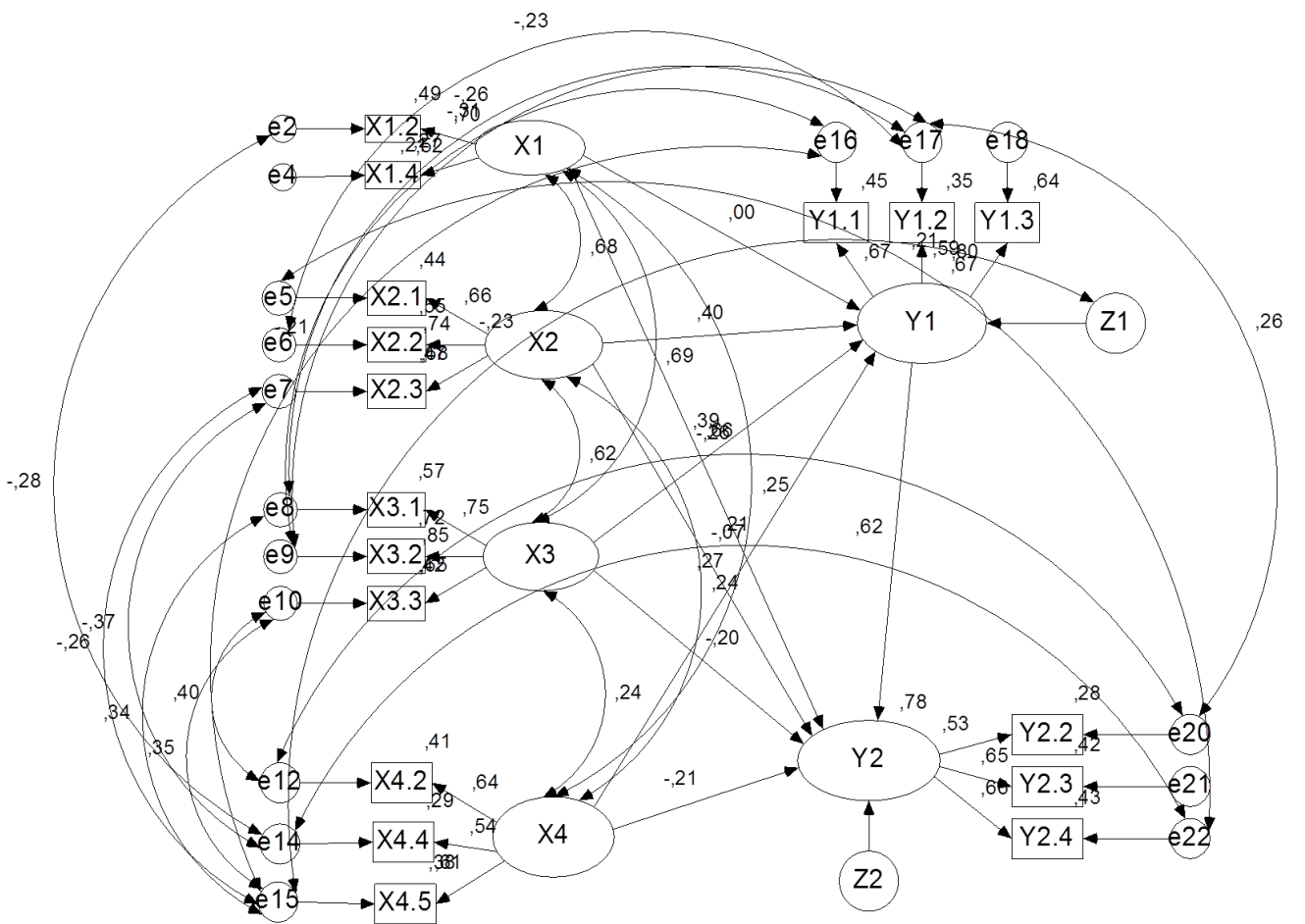

Chi Square: 101,479

Prob:, 154

df:88

RMSEA: 034

GFI:,925

AGFI:,870

TLI: 970

CFI:,981

Figure 3. Results of final-stage SEM analysis 


\subsection{Hypothesis Testing}

Hypotheses of this study were tested by partially testing each of the paths of direct effects from the results of structural equation modeling (SEM). Testing of the direct effect hypothesis indicated the value of C.R. $>1.96$ and $P<0.05$, meaning that the effect was significant. Testing of the indirect effects is the side effect of direct effects. The coefficient of indirect effects was obtained by multiplying the coefficients of direct effects that formed it. If the multiplying coefficient of direct effects was significant, results of the testing of indirect effects were considered significant. (Ferdinand, 2000: page 167) Results of hypothesis testing are shown in Table 1.

\begin{tabular}{|c|c|c|c|c|}
\hline \multirow[b]{2}{*}{ Independent Variable } & \multirow{2}{*}{$\begin{array}{l}\text { Dependen } \\
\text { Variable }\end{array}$} & \multicolumn{3}{|c|}{ Path Coefficient Direct Effect } \\
\hline & & $\begin{array}{c}\text { Koef. } \\
\text { Standardize }\end{array}$ & $p$-value & Information \\
\hline Industrial environment & Corporate strategy & -0.003 & 0.988 & Non Significant \\
\hline Operating environment & Corporate strategy & 0.397 & 0.024 & Significant \\
\hline Remote environment & Corporate strategy & 0.388 & 0.025 & Significant \\
\hline Internal environment & Corporate strategy & 0.269 & 0.033 & Significant \\
\hline Industrial environment & Performance & 0.657 & 0.783 & Non Significant \\
\hline Operating environment & Performance & 0.069 & 0.029 & Non Significant \\
\hline Remote environment & Performance & -0.195 & 0.443 & Non Significant \\
\hline Internal environment & Performance & -0.207 & 0.200 & Non Significant \\
\hline Corporate strategy & Performance & 0.617 & 0.054 & Significant \\
\hline
\end{tabular}

Table 1 . Results of hypothesis testing

\subsubsection{Effects of Industrial Environments on Corporate Strategy}

Xx Results of hypothesis testing showed that the hypothesis of a significant effect of the industrial environments on diversification strategy was rejected. Results of the analysis provided a standardized path coefficient of -0.003 with a p-value of 0.988 ; thus, results of hypothesis testing were considered non-significant. These results rejected the first hypothesis that the industrial environments significantly influenced the corporate strategy of manufacturing industries. The stronger the pressure of industrial environments such as the threat of new entrants, the power of buyers and suppliers and threat of substitute products, the more the company would implement the corporate strategy. Hitt et al. (2005: page 40) argues that the industrial environments affect the company's strategic options, as well as the decisions made on the basis of such options. Pearce and Robinson (2003: page 77) suggest that competitive force is not only caused by intra-industrial competition, but also competition caused by the underlying economic situations. In fact, at the time of this study the economic situations have not recovered from the global crisis. The fact proved that the challenges and 
threats of industrial environments affected corporate strategy, but it was in a negative direction.

Results of the descriptive analysis indicated that, in the face of the conditions of industrial environments that have not recovered from the global crisis, most companies studied preferred a concentric diversification strategy (creating new products with technological linkage to existing products). These results supported the study conducted by Nurhayati (2004) that showed that environmental factors of the industry did not significantly affect the strategy. This study was inconsistent with those of Hidayat (2004) and Hidayat and Hairil (2009). Hidayat (2004) found that industrial environments had a significant effect on the determination of the marketing strategies. Hidayat and Hairil (2009) revealed that industrial environmental factors had effects on diversification strategy.

\subsubsection{Effects of the Operating Environments on Corporate Strategy}

Results of the testing of the second hypothesis showed that the hypothesis of a significant effect of the operating environments on corporate strategy was accepted. Results of the analysis provided a standardized path coefficient of -0.397 with a $p$-value of 0.024 ; thus, results of hypothesis testing were considered significant. These results supported the second hypothesis that the operational environments had a significant effect on the corporate strategy of manufacturing companies. Results of this study revealed a tendency that the factors of the corporate operating environments affected the corporate strategy. The extent of improved capability of the operating environments as characterized by increased competitive position of the company, the company's reputation in the eyes of suppliers, the company's reputation in the eyes of creditors, the ability to recruit reliable human resources, and research and development capabilities proved to be capable of altering corporate strategy. Manufacturing firms tended to alter their strategies tailored to the operating environments that showed improved conditions.

These results supported the theory of an interrelationship between the operating environments and corporate strategy. Pearce and Robinson (2003: page 174) suggests that an internal analysis should identify the strengths and weaknesses underlying corporate strategy. Managers should develop an assessment of the company's key strengths on the basis of the correspondence between those strengths and the existing or expected market opportunities so that managers can eventually develop a series of corporate strategic measures. These results were understandable given that the managers more carefully addressed the improvement in operating conditions of the company.

Hitt et al. (2005: page 80) related the operating environments to the capability and competence of the company. The decisions made by the managers with regard to resources, 
capabilities and core competencies had significant effects on the company's ability to make important strategic decisions, including those relating to market entry or exit, investment in new technology, building of new or additional manufacturing capabilities and establishment of strategic cooperation. This finding also supported studies conducted by Nurhayati (20034, Hidayat (2004), Hidayat and Hairil (2009) and Lee (2010). Nurhayati (2004) found that the operating environments had positive significant effects on competitive strategy. Hidayat (2004) argued that the operating environments had positive significant effects on marketing strategy. Hidayat and Hairil (2009) suggested that the operating environments significantly affected diversification strategy. Lee (2010) maintained that almost all operating environmental factors had effects on the choice of the company's business strategy, except the level of competition. These findings suggested that the effectiveness of the company's strategy would largely depend on the company's attention to their operating environmental factors.

\subsubsection{Effects of Remote Environments on Corporate Strategy}

Results of the testing of the third hypothesis showed that the hypothesis of a significant effect of the remote environments on corporate strategy was accepted. Results of the analysis provided a standardized path coefficient of 0.88 with a p-value of 0.025 ; thus, results of hypothesis testing were considered significant. These results supported the third hypothesis that the remote environments had a significant effect on the strategy of manufacturing firms. In order to relate the company to its environments, an environmental analysis and diagnosis is necessary, which in turn could produce strategies that are based on and considering the remote environments of the industry. Opportunities and threats should be considered prior to developing strategies.

Remote environments include those factors external to the company's operations. At the time this study, the conditions of the manufacturing industry were more influenced by macroeconomic conditions, which have not recovered from the global crisis. These conditions were also exacerbated by the rise in fuel prices in 2013 and political conditions (East Java gubernatorial election in 2013), as well as ahead of the legislative elections in 2014. Analysis of the remote environments was used by companies to successfully address those remote environmental factors both by means of offense and defense with regard to formulating strategies that took advantage of the opportunities or that minimized the threats. Changes in remote environments could affect changes in consumer demands for industrial products and consumer services. Recognizing and evaluating the opportunities and threats brought about by the remote environments rendered organizations capable of developing a clear vision and mission and designing strategies to achieve long-term objectives as well as developing policies to achieve the annual targets. Remote environments include demographic, economic, natural, technological, political, legal and socio-cultural as well as security factors. 
In the global era in which the environments change dynamically and often turbulently industries require strategies capable of making companies closer to their goals. In other words, companies are always required to achieve optimal performance. Wheelen and Hunger (2012: page 87 ) maintains that a strategy should be formulated by taking the environments into account. Strategy is a unified, broad and integrated plan linking corporate excellence to the environmental challenges, designed to ensure that the main goals are achieved. The concept of equivalence holds that the good performance of the company is affected by the choice of strategy and the strategy chosen is affected by environmental factors (Nandakumar, Ghobadian \& O'Regan, 2010). Oyewobi, Wndapo and Rotimi (2013), Tan, Shen and Langston (2012) concluded that dimensions of business environment have moderating effects on organisational strategies.

\subsubsection{Effects of the Internal Environments on Corporate Strategy}

Results of the testing of the fourth hypothesis showed that the hypothesis of the significant effects of internal environments on corporate strategy was accepted. Results of the analysis provided a standardized path coefficient of 0.268 with a $p$-value of 0.033 ; thus, the results of hypothesis testing were considered significant. These results supported the fourth hypothesis that the internal environments had significant effects on the strategy of manufacturing firms. In making corporate strategy decisions, managers are strongly influenced by the internal conditions of their companies. The company's internal conditions such as an excellent research and development, abundant human resources and healthy corporate financial and accounting conditions affect the strategies adopted by managers. Results of this study agree with those of Ward and Duray (2000) that, in the long term, the company's internal environments strongly influence corporate strategy but, in the short term, the effect would be relatively small. Kariuki, Awino and Ogutu (2011) argues that the internal environments have direct impacts on corporate strategy. Consistent with this notion, Mason (2007); Babatunde and Adebisi (2012) reveal the fact that some companies have better internal environmental (accounting and financial) conditions that other companies. In fact, it turns out that most of those companies adopt new strategies at the time of their internal conditions improve.

The Heckscher-Ohlin model shows that corporate strategy is directly related to the internal (workforce) environmental factors in a country (Bernhofen \& Brown, 2011). For example, companies in a country with a relatively more abundant workforce have an advantage in terms of corporate strategy relative to those companies in a country with less abundant workforce (Forman \& Lancioni, 2002). Internal (marketing and distribution) conditions of the company significantly contribute to influencing corporate strategy chosen. Thus, the relative profitability associated with the company's internal conditions would affect corporate company. Results of 
the study conducted by Kabadayi, Eyuboglu and Thomas (2007) indicated that the internal factors affected managers in strategy decision making.

\subsubsection{Effects of Industrial Environments on Performance}

Results of the testing of the fifth hypothesis showed that the hypothesis of a significant effect of industrial environments on performance was rejected. Results of the analysis provided a standardized path coefficient of 0.657 with a $p$-value of 0.783 ; thus, the results of hypothesis testing were considered non-significant. These results rejected the fifth hypothesis that the industrial environments had significant effects on the performance of the manufacturing industry. The findings of this study indicated that the stronger the pressures of industrial environments the more the performance of the manufacturing industry would decline. Managers will immediately respond to any changes in the industrial environments in order to maintain and sustain their companies' performance.

These results were inconsistent with the theory of Hitt et al. (2005: page 55) that, in comparison to other environmental factors, the industrial environments have stronger direct effects on performance. The intensity of competition in the industry and potential industry earnings are a function of the five competitive forces: the threat of new entrants, the power of buyers, the power of suppliers, the threat of substitute products and competition among industry members.

Pearce and Robinson (2003: pages 78-92) argue that the competition among members of the industry occurs because they jockey for position by using various tactics such as price competition, product introduction and advertising war. Such a fierce competition results from a number of factors such as the growing number of players within in an industry, the slow growth of the industry and the higher costs. As a result, it causes a decline in profits and havoc in the industry, resulting in a decrease in the performance of the industry.

The power of buyers can also affect the performance of the industry. In a situation of fierce competition, buyers or customers may depress prices, demand higher quality or better service and pit among fellow members of the industry, all of which can reduce industry profits. The power of buyers can have high bargaining power due to: (1) the limited and concentrated number of suppliers; (2) unique and differentiated product suppliers; (3) suppliers' ability for forward integration and (4) the industry being not an important customer for the suppliers.

Based on interviews with some respondents, the manufacturing industry was faced with the pressure of competition, the pressure of customers and the pressure of suppliers that affect the company's revenue. Results of descriptive analysis proved that the indicator supplier had an average higher score than other indicators. This proved that the power of suppliers was 
dominant in influencing the decline in industry performance. Results of this study supported those of Nurhayati (2004) and Hidayat (2004) that the industrial environments had nonsignificant effects on the performance of the industry. Furthermore, Hidayat and Hairil (2009) argue that the industrial environments had no significant effect the performance of the industry. The stronger the pressure of the industrial environments the lower the performance of manufacturing industry will be.

\subsubsection{Effects of the Operating Environments on Performance}

Results of the testing of the sixth hypothesis showed that the hypothesis of the significant effects of the operating environments on performance was rejected. Results of the analysis provided a standardized path coefficient of 0.069 with a $p$-value of 0.029 ; thus, the results of the hypothesis testing were considered non-significant. These results rejected the sixth hypothesis that the operating environments had significant effects on the performance of the manufacturing industry. Results of this study revealed a tendency that the operating environmental factors of the company were capable of considerably contributing to the improvement in performance; however, this was not proven in this study. At the time of this study, the performance of the manufacturing industry was more influenced by the macro-economic conditions that have not recovered from the global crisis. This condition was also exacerbated by the increase in fuel prices and the heated political conditions after the election for governor of East Java and ahead of legislative elections in 2014.

These results were inconsistent with the theory of Parnell (2013) that the survival of a company ultimately depends on the ability to preserve the resources of the operating environments. These findings were also inconsistent with those of Nurhayati (2004) and Hidayat (2004) who found that the operating environments had a positive significant effect on the performance of the company. Meanwhile, David (2013: page 171) maintains that the competitive position of the company, the company's reputation in the eyes of suppliers, the company's reputation in the eyes of creditors, the ability to recruit reliable human resources and capacity for research and development represent the core of a business process. The present study supported the results of the study conducted by Hidayat and Hairil (2009) the operating environments had no significant effect on the performance of the company. Hence, the operating environments should have a substantial effect on performance, but this study showed no significant relationship. 


\subsubsection{Effects of the Remote Environments on Performance}

Results of the testing of the seventh hypothesis showed that the hypothesis of the significant effects of the remote environments on performance was rejected. Results of the analysis provided a standardize path coefficient of -0.195 with a $p$-value of 0.443 ; thus, the results of the hypothesis testing were considered non-significant. These results rejected the seventh hypothesis that the remote environments had a significant effect on the performance of the manufacturing industry. This condition was caused by the poor remote environmental conditions that were not stable due to the global recession and the high political risks. Poor performance was likely due to the uncertain economic situations caused by the global economic crisis, leading to managers' preferring to maintain the existing performance.

The remote environments include demographic, economic, natural, technological, political, legal and socio-cultural as well as security factors. Economic factors have a significant direct effect on the performance of the industry since the patterns of consumption are influenced by the relative prosperity of various segments of the market that affect the industry. Social factors have a major impact on all products, services, markets and customers. Social factors affecting companies are beliefs, values, attitudes, opinions, and lifestyles of the people in the external environments of the company, which have been evolving from the influences of culture, ecology, demography, religion, education, and ethnicity. Political factors determine the legal and regulatory parameters that limit the operation of the company. Political constraints are imposed on the company through the decisions regarding fair trade, antitrust laws, taxation program, the minimum wage provisions, policies on pollution and pricing, administrative boundaries, and many more measures intended to protect workers, consumers, the general public and the environment.

Technological changes and revolutionary inventions have dramatic impacts on the company. The Internet represents a global and national economic engine that boosts productivity, a key factor for raising standards of living and saving billions of dollars for distribution and direct sales transaction costs for self-serving systems. The Internet alters various opportunities and threats by changing the product life cycle, increasing distribution speed, creating new products and services, removing market geographic boundaries and historically changing the trade off between flexibility and standardization of production. The Internet also alters the economic scale, changes the entry barriers and redefines the relationship between the industry and various suppliers, creditors, customers and competitors. Based on interviews with several respondents and observations of the macro-economic conditions, most manufacturing industries were faced with a crucial problem. On the one hand, the level of competition was growing fiercer but, on the other hand, the macro-economic conditions remained uncertain. With regard to the macroeconomic conditions, manufacturing industry was faced with high costs due to the rise in fuel prices, the demands for increasing workers' wages and so on. Hence, the remote environments should have substantial effects on performance, but this 
study showed no significant relationship since the remote environmental conditions were indeed unstable. Results of this study were inconsistent with those of the previous studies. Hidayat and Hairil (2009) argued that the remote environmental factors had effects on the performance of the company. Oyewobi et al. (2013); Tan et al. (2012) concluded that dimensions of business environment have moderating effects on organisational performance.

\subsubsection{Effects of the Internal Environments on Performance}

Results of the testing of the eighth hypothesis showed that the hypothesis of the significant effects of the internal environments on performance was rejected. The results of the analysis provided a standardize path coefficient of -0.207 with a $p$-value of 0.200 ; thus, the results of the hypothesis testing were considered non-significant. These results rejected the eighth hypothesis that the internal environments had a significant effect on the performance of the manufacturing industry. These results were inconsistent with the theory that reveals that the higher the ability of the company's internal environments, the higher the performance will be. Parnell (2013: page 43) maintains that the company's performance will ultimately depend on the company's ability to maintain and manage the resources of its internal environments. Meanwhile, David (2013: page 171) argues that the marketing and distribution, research and development, operations and production management, human resources and finance and accounting are the core part of most businesses. Internal audit is crucial to determine whether a business organization is healthy or not. Therefore, many organizations that are successful in internal audit and capable of achieving competitive advantages could eventually improve their performance.

Hitt et al. (2003: page 81) suggests that an effective analysis of the internal environments is how to exploit the company's core competencies and meet the standards of competition that have impacts on the customer value creation. It is this value that will produce performance in the form of corporate profits. These findings were also inconsistent with those of Nurhayati (2004), Hidayat (2004), Sougata (2004) and Hidayat and Hairil (2009) that the internal environments had positive significant effects on performance of the company.

\subsubsection{Effects of Corporate Strategy on Performance}

Results of the testing of the ninth hypothesis showed that the hypothesis of the significant effects of corporate strategy on performance was accepted. Results of the analysis provided a standardized path coefficient at 0.617 with a p-value of 0.054 ; thus, the results of hypothesis testing were considered significant. These results supported the ninth hypothesis that corporate strategy had significant effects on the performance of the manufacturing industry. 
This finding implied that the higher the level of diversification, the higher the performance of the manufacturing industry would be.

Under conditions of high uncertainty as at the time of this study, a manager is required to be able and keen in determining the right strategy, which in turn will improve the company's competitiveness. Results of the descriptive analysis showed that, in the current unfavorable, most of the studied industries preferred concentric diversification strategy (creating new products with technological linkage to the existing ones). This could be observed from the respondents' answers to the statement regarding technological linkage among products with a score of 3.68 or most of them agreed with the statement. Beal (2000) observed that the quantity of diversification affected profitability or, in other words, empirically demonstrated an association between diversification and performance. This study supported previous studies conducted by Forman and Hunt (2005), Ellitan (2006), Anatan (2006) and Hidayat and Hairil (2009), as well as Suroso (2009) that corporate strategy had a significant effect on the performance of the company.

\section{Conclusion}

Results indicated that environmental factors (not the industrial environments) had a significant effect on the corporate strategy of manufacturing industries in Indonesia. Environmental factors had non significant effects on the performance of manufacturing industries in Indonesia. The corporate strategy had significant effects on the performance of manufacturing industries in Indonesia. Internal and external environmental factors through the operating and remote environments had effects on the strategy of manufacturing companies in Indonesia. However, both internal and external environments did not affect the performance of manufacturing companies in Indonesia. There was a tendency that manufacturing companies were to observe the occurring macro-economic conditions. At the time of this study was conducted (in 2013/2014), the strategy of the manufacturing companies was more influenced by macro-economic conditions that have not recovered from the global crisis. This condition was also aggravated by the rise in fuel prices in 2014 and ahead of legislative and presidential elections in 2014. It is suggested for further research to add variable and indicator involved. In addition, using integration of quantitative and qualitative approach is recommended to get a better understanding about diversification strategy. This analysis would enhance scientific information related with environment factor, strategy and manufacture industries performance. 


\section{References}

Anatan, L. (2006). Agile Supply Chain: Through Competitive Excellence. Sinergi, 8(1), Hal. 13-21.

Babatunde, B.O., \& Adebisi, A.O. (2012). Strategic Environmental Scanning and Organization Performance in a Competitive Business Environment. Economic Insights - Trends and Challenges, 64(1), 24-34.

Beal, R.M. (2000). Competing effectively: environmental scanning, competitive strategy and organisational performance in small manufacturing firms. Journal of Small Business Management, 38(1), 27-47.

Bernhofen, D.M., \& Brown, J.C. (2011). Testing the General Validity of the Heckscher-Ohlin Theorem: The Natural Experiment of Japan. CESifo Working Paper Series, No. 3586. http://dx.doi.org/10.2139/ssrn.1965962

Chi, T., Kilduff, P.P.D, \& Gargeya, V.B. (2009). Alignment between business environment characteristics, competitive priorities, supply chain structures, and firm business performance. International Journal of Productivity and Performance Management, 58(7), 645-669. http://dx.doi.org/10.1108/17410400910989467

Collis, D.J., \& Montgomery, C.A. (2005). Corporate strategy: resources and the scope of the firm. 2nd edition. USA: McGraw-Hill.

David, F.R. (2013). Strategic Management. Concepts and Cases. Harlow: Pearson Education Ltd.

Dumairy. (2000). Indonesian Economy. Jakarta: Erlangga.

Ellitan, L. (2006). Innovation Strategy and Performance Manufacturing Company in Indonesia: Model Approach Simultaneous and Sequential Model. Journal of Management, 6(1).

Ferdinand, A. (2000). Structural Equation Modeling in Management Research: Applications Complex Models in Research for Thesis and Dissertation. 2th Editions. Semarang: Diponegoro University.

Forman, H., \& Lancioni, R. (2002). The determinants of pricing strategies for industrial products in international markets. Journal of Business-to-Business Marketing, 9(2), 29-64. http://dx.doi.org/10.1300/J033v09n02_03

Forman, H., \& Hunt J.M. (2005). Managing the influence of internal and external determinants on international industrial pricing strategies. Industrial Marketing Management, 34, 133-146. http://dx.doi.org/10.1016/j.indmarman.2004.07.011 
Ghozali, I. (2009), The Application of Multivariate Analysis with SPSS. $4^{\text {th }}$ Editions. Semarang: Diponegoro University.

Hidayat, I. (2004). Determinants of Marketing Strategy and Corporate Performance: Study Results Cement Industry Managers. Entrepreneur Magazine, 6, 11-19.

Hidayat, R., \& Hairil, B. (2009). Influence of Environmental Factors to Strategies and Performance Manufacturing Industry in East Java. Semesta Journal, 12(1), 11-21.

Hitt, M.A., Ireland, R.D., \& Hoskisson, R.E. (2005). Strategic Management. Competitiveness and Globalization. Mason, Ohio: South Western, Thomson.

Kabadayi, S., Eyuboglu, N., \& Thomas, G.P. (2007). The performance implications of designing multiple channels to fit with strategy and environment. Journal of Marketing, 71(4), 195-211. http://dx.doi.org/10.1509/jmkg.71.4.195

Kariuki, P.M., Awino, Z.B., \& Ogutu, M. (2011). Effect of Firm Level Factors, Firm Strategy, Business Environment on Firm Performance. Business Environment Journal, 1-27.

Kline, R.B. (2011). Principles and Practice of Structural Equation Modeling. 3rd ed. New York: The Guilford Press.

Kotler, P., \& Armstrong, G. (2013). Principle of Marketing. 14th edition. New Jersey: Prentice Hall.

Lee, R.P. (2010). Extending the Environment-Strategy-Performance Framework: The Roles of Multinational Corporation Network Strength, Market Responsiveness, and Product Innovation. Journal of International Marketing, 18(4), 58-73. http://dx.doi.org/10.1509/jimk.18.4.58

Mason, R.B. (2007). The external environment's effect on management and strategy A complexity theory approach. Management Decision, 45(1), 10-28.

http://dx.doi.org/10.1108/00251740710718935

Mustafa, Z., \& Wijaya, T. (2012). Techniques Guide SEM and PLS statistics with SPSS AMOS. Yogyakarta: Cahaya Atma Pustaka.

Nandakumar, M.K., Ghobadian, A., \& O'Regan, N. (2010). Business-level strategy and performance: The moderating effects of environment and structure. Management Decision, 48(6), 907-939. http://dx.doi.org/10.1108/00251741011053460

Nurhayati (2004). Analysis of factors that affect the performance and competitive advantage in export-oriented small businesses in East Java. Disertation Unpublish. Brawijaya University. 
Oyewobi, L.O., Windapo. A., \& Rotimi, J.O.B. (2013). The effects of business environments on corporate strategies and performance of construction organisations In Smith, S.D. \& Ahiaga-Dagbui, D.D. (Eds.). Procs $29^{\text {th }}$ Annual ARCOM Conference. 2-4 September. Reading, UK, Association of Researchers in Construction Management, 691-701.

Parnell, J.A. (2013). Strategic Management: Theory and Practice. 4th ed. Sage Publications.

Pearce, J.A. \& Robinson, R.B. (2003). Strategic management: formulation, implementatio and control. Boston: Richard D. Irwin.

Sougata, R. (2004). Environment-strategy-performance linkages: A study of Indian firms during economic liberalization. Vikalpa, 29(2), 9-23.

Tan, Y., Shen, L., \& Langston, C. (2012). Competition environment, strategy, and performance in the Hong Kong construction industry. Journal of Construction and Engineering Management. 138(3), 352-360. http://dx.doi.org/10.1061/(ASCE)CO.1943-7862.0000407

Ward, P.T., \& Duray, R. (2000) Manufacturing strategy in context: environment, competitive strategy and manufacturing strategy. Journal of Operations Management. 18(2), 123-138. http://dx.doi.org/10.1016/S0272-6963(99)00021-2

Wheelen, T.L., \& Hunger, J.D. (2012). Strategic Management and Business Policy. Toward Global Sustainability. 13th ed. Boston: Pearson Education, Inc., publishing as Prentice Hall.

Journal of Industrial Engineering and Management, 2015 (www.jiem.org)

Article's contents are provided on a Attribution-Non Commercial 3.0 Creative commons license. Readers are allowed to copy, distribute and communicate article's contents, provided the author's and Journal of Industrial Engineering and Management's names are included. It must not be used for commercial purposes. To see the complete license contents, please visit http://creativecommons.org/licenses/by-nc/3.0/. 